\title{
START-UP PROGRAMS FOR SELF-EMPLOYMENT: WHO ARE THE SUCCESSFUL BENEFICIARIES OF THE PROGRAMS FOR UNEMPLOYED? A CASE STUDY OF HUNGARY
}

\author{
Petr Suler ${ }^{1, a, *}$, Zsuzsanna Naár-Tóth ${ }^{2, b}$ and Cristina Manole ${ }^{3, c}$ \\ ${ }^{1}$ The Institute of Technology and Business in Ceske Budejovice, The School of Expertness and \\ Valuation, Okruzni 517/10, 37001 Ceske Budejovice, Czech Republic \\ ${ }^{2}$ Faculty of Economics and Social Science, Institute of Economics, Business Law and Methodology, \\ Management and Business Administration Doctoral School, Szent István University, H-2100, \\ Gödöllő, Páter Károly utca 1, Hungary \\ ${ }^{3}$ The Faculty of Administration and Public Management, The Bucharest University of Economic \\ Studies, 6 Piata Romana, 1st district, Bucharest, \\ 010374 Romania

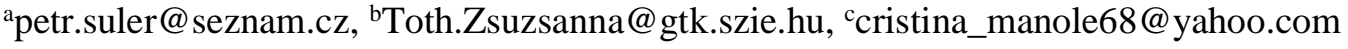 \\ *Corresponding author
}

Cite as: SULER, P., NAÁR-TÓTH, Z., MANOLE, C. (2019). Start-up programs for self-employment: Who are the successful beneficiaries of the programs for unemployed? A case study of Hungary, Ekonomicko-manazerske spektrum, 13(2), 98-108.

Available at: dx.doi.org/10.26552/ems.2019.2.98-108

\begin{abstract}
In this article, we focused on the analysis of beneficiaries of start-up incentives interventions in Hungary, which are designed for unemployed individuals to start a business in the form of self-employment. The support is provided in the form of a lump-sum payment and the treated participant is then obliged to maintain self-employment during the stipulated mandatory period. As a success of an instrument is considered to the fact that the pursuit of self-employment continues beyond this mandatory sustainability period. Using the tools of qualitative data analysis, we investigated the dependence between the characteristics of treated individuals and their success of the implemented intervention. In the analysis, we found that the sex of the beneficiaries, age category, and disadvantages significantly affect their success and vice versa, the level of education does not have a significant impact on whether individuals remain in the labor market as self-employed in the long term.
\end{abstract}

Keywords: active labour market policy; intervention; self-employment; association.

JEL Classification: J08, C5, D04

\section{Introduction}

Interventions provided to the unemployed are active labor market policy instruments by which countries, as well as the European Union, through the European Social Fund, seek to reduce unemployment rates, help jobseekers place themselves on the labor market, obtain or improve their abilities and working skills that can be attractive to potential future employers. (Tokila, 2009) One such form of assistance for jobseekers is the program that helps individuals to start a business in the form of self-employment. These interventions are usually provided in the form of a contribution to a business start-up, according to Bergemann and Berg (2008). Beneficiaries of this intervention are then obliged to maintain their business during the 
mandatory period. The question is, however, whether the resources for these forms of aid are spent effectively. (Hottenrott and Richstein, 2020) If the funds are spent efficiently, the intervention will bring the desired effect in the form of employment for jobseekers who have started their business in this form but have operated it not only during the mandatory period but have continued also after it (Svabova et al., 2019a). Maintaining self-employment beyond the mandatory sustainability period can be considered a positive outcome of the intervention (Blanchflower and Oswald, 1990). Its aim is therefore not only to financially, or otherwise, help individuals to start self-employment but also to place them on the labor market for a longer period of time. Thus, as a positive impact of treatment, a long-term effect on maintaining selfemployment is considered.

The success of a jobseeker in such a program depends on many factors, including his / her characteristics and also the characteristics of the environment in which the jobseeker lives and works. (Verheul, 2012, Crepon et al., 2013) In this article, we, therefore, focused on analyzing individuals who were beneficiaries of the treatment to start self-employment in Hungary in 2015. We know about these individuals whether they have been self-employed for longer than the mandatory period ( 3 years), and therefore whether the intervention was for them successful. By analyzing the characteristics of individuals and their impact on the success of the program, we find out which factors have a significant impact on the success of the intervention.

The article is divided into five parts. The introduction outlined the basis of the issue and includes a literature review. The second chapter focuses on the description of the methods used in this study to analyze the dependencies between individual characteristics and their success in self-employment. The third chapter contains a description of the data file about jobseekers from Hungary used in this study. The fourth chapter provides the results of the dependency analysis. The discussion and conclusion summarize the findings and outlines the direction of the study.

\subsection{Labour market programs in Hungary}

Employment relations in Hungary are governed by the Act I of 2012 on Labour Code and other labour law legislation, collective bargaining agreements and individual employment contracts. In Hungary, the term "unemployed" is defined according to the International Labor Organization (ILO), and statistics about unemployed people are based on labor force sample survey data. The term "registered jobseeker" is defined by the Act. Under this Act, a registered jobseeker is a person who:

- fulfills all the conditions necessary to start a job,

- does not attend full-time education at any educational institution,

- is not entitled to a retirement pension or rehabilitation allowance,

- is not employed or performs any other (excluding temporary) employment;

- cooperates with the local labor office in finding a job;

- has been registered with the PES as a job seeker.

According to the Act, a long-term unemployed person is a person, whose period of continuous registered unemployment lasts for at least 12 months. The number of registered jobseekers comes from the database of unemployment, managed by the Public Employment Services (PES), in Hungarian Nemzeti Foglalkoztatási Szolgálat.

In Hungary, participants in the public works schemes are officially considered as employed at the time of their participation in them. Thus, in the implemented unemployment statistics, these individuals are not considered to be registered unemployed, although they are still required to contact the local PES. Participants in these public work schemes are in fact not employed in the primary labor market and their "wages" are paid by the state and are lower than 
the wages they would earn on the labor market. According to Fertig and Csillag (2015), the estimated number of long-term unemployed (quasi-registered) is about $50 \%$ higher than the official number and this difference is due to the above-mentioned official definition of program participants as employed. The assignment of clients to labor market programs are not specifically targeted or statistically profiled and the jobseekers are in general not categorized. The contribution is based on centrally set eligibility rules and also is based at the discretion of the officer at the PES office.

The intervention we are focusing on in this study is provided in Hungary under active labor market policy instruments, in category 7 of the group "Labor Market Policy Measures": Startup incentives. From the year 2003 until 2014 it was provided in the form of "Assistance for self-employment". From 2003 until 2007 and then from 2015 it is provided as "Assistance for unemployed persons to become entrepreneurs". The sources of funding of programs supporting the unemployed to start self-employment in Hungary are both national funds (National Employment Fund) and the European Social Fund. The following figure shows the expenditure incurred on these two programs from 2003 to 2017. The figures are converted from HUF to millions of Euros.

Figure 1: Expenditure by Start-up incentives in Hungary

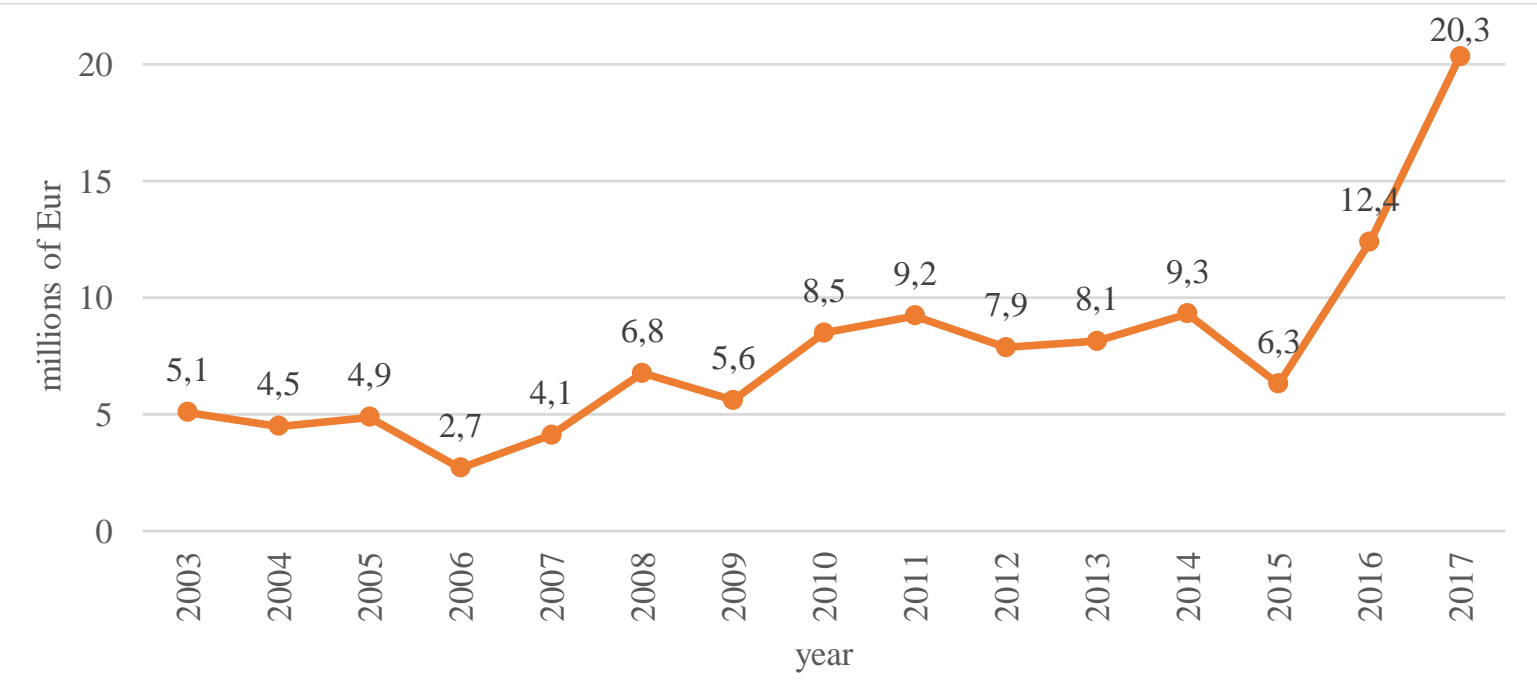

Source: Own processing

These funds were provided in full to the beneficiaries of the intervention programs. Contributions were paid in the form of a lump-sum payment. In addition to the two types of support in Hungary, the group of Start-up incentives includes another intervention, namely "Start-up incentives for disabled persons", but which from 2006 to the present is not applied. The other two interventions were used every year of their implementation. The following figure shows the numbers of individuals who participated in the programs Assistance for selfemployment and Assistance for unemployed persons to become entrepreneurs between 2003 and 2017.

In the same figure, their share in the total number of participants in all LMP measures is also shown. In some years, there are no available data on the total number of participants in LMP measures, therefore the percentages in Figure 2 are not shown. Over the last few years, they were around 1 to $2 \%$ of all treated participants. 
Figure 2: Participants of Start-up incentives in Hungary

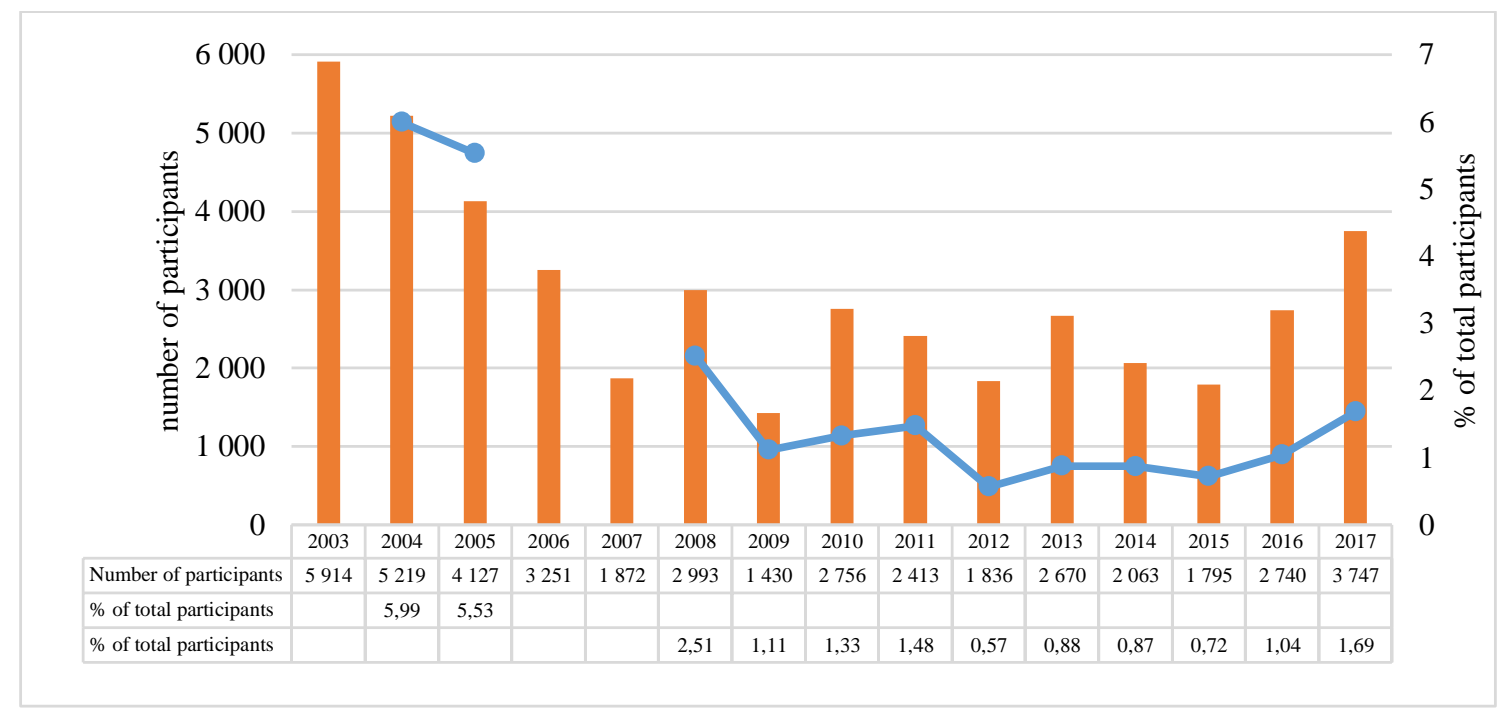

Source: own elaboration

The number of participants in these start-up programs was around 5,000 in 2003 and 2004. In recent years, the number has varied but has ranged around 2,000 participants. In 2017, together 3,747 individuals participated in the two programs. The following figure shows the share of the expenditure for these two programs in the total amount of LMP measures (categories 2-7).

Figure 3: Proportion of expenditures for Start-up incentives on total LMP measures in Hungary

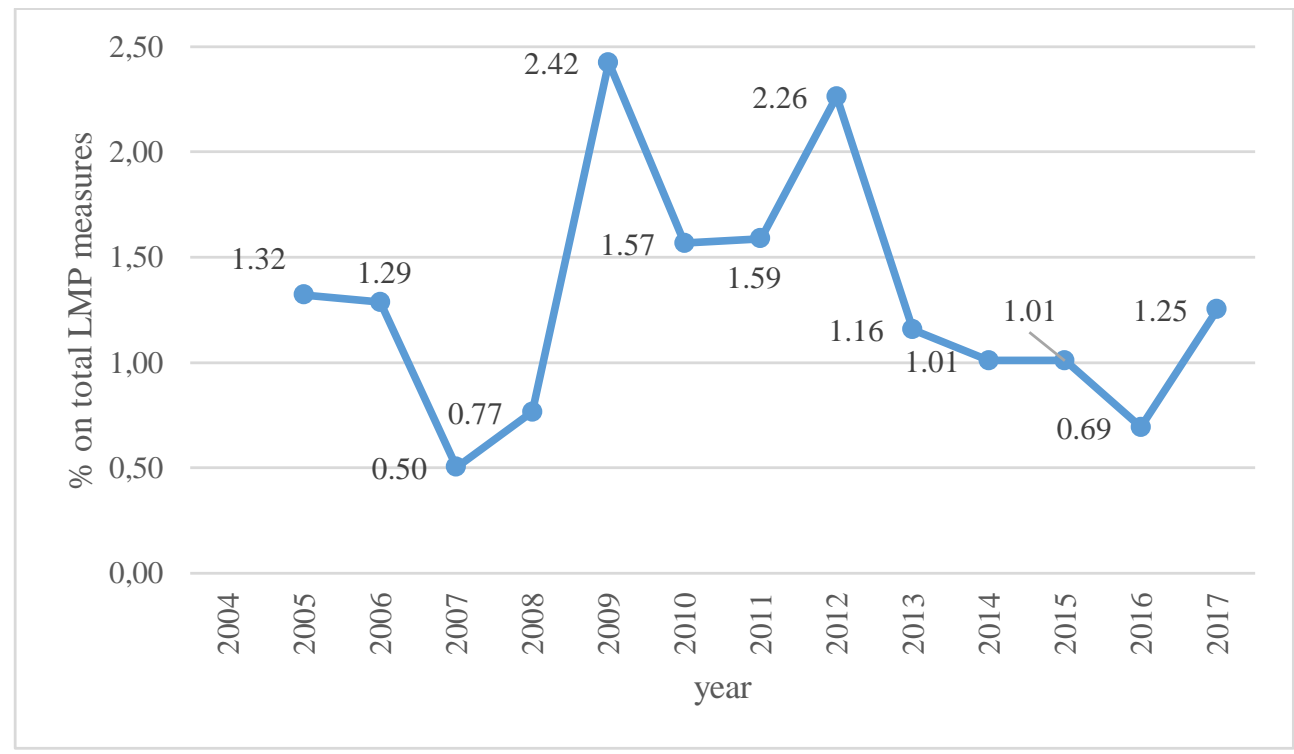

Source: Own processing

One of the eligibility criteria is the need to contribute at least $20 \%$ of own resources, the provision of collateral and the mandatory maintenance of a registered business for at least three years. The program is not aimed at a selected target group of the unemployed (e.g. long-term unemployed or low-educated). However, the allocation system is managed by the district-level public employment service offices and local authorities have the possibility to target the allocation system to specific groups. However, in view of the eligibility criteria, in particular, the requirement for $20 \%$ own resources co-financing, this intervention is not widely used by 
young graduates or older people. Also for disadvantaged unemployed groups, this own resources requirement is usually unbearable.

In addition to the existing two self-employment programs, two new start-ups were introduced in Hungary, targeting young people under 30 years of age (GINOP 5.2.7) and jobseekers over 30 years of age (GINOP 5.1.10). They both are co-financed by the ESF. These two programs provide higher grants and the beneficiaries do not have to have their own resources, making the interventions more accessible to a wider group of unemployed. These two programs are part of the Operational Program for Economic Development and Innovation.

\subsection{Profile of self-employed persons in Hungary}

Hungary Country Note (2018) provides the characteristics of self-employed persons in Hungary. Most of them, as in the EU, worked in four sectors in 2017: wholesale and retail (16.4 $\%)$, agriculture, forestry and fishing $(14.1 \%)$, construction $(13.7 \%)$ and professional, scientific and technical $(12.0 \%)$. There was little difference between men and women in the employment sectors in that women were more often employed in the professional, scientific and technical sectors than men $(17.0 \%$ vs. $8.5 \%)$ and less in construction $(3.4 \%$ vs. $19 \%)$.

As regards the level of education of the self-employed, a small proportion of them has less than secondary education (5.1\%, which is below the EU average). In contrast, $29.5 \%$ of selfemployed persons have a university degree in Hungary, compared to $35.1 \%$ in the EU. The differences between the sexes in education are small, the only difference being mentioned in the context of higher education, which has $33.7 \%$ for self-employed women compared to $27.3 \%$ for men.

The rate of self-employment in Hungary over time also varies considerably according to the level of education. In the low-educated group, there is a slight downward trend in selfemployment (5.3\% in 2008, 5.1\% in 2017), which is a much lower percentage of the use of this form of entrepreneurship compared to the EU (20.1\% in 2017). There are no significant differences in the use of self-employment between men and women. Overall, however, the proportion of self-employed persons in Hungary is decreasing - with the exception of youth and women.

\subsection{Literature review}

A number of studies by authors in the countries of the European Union deal with the evaluation of the success of political programs for unemployed. Most such evaluations have been carried out in Germany in recent years. For example, Wolff (2012) evaluated a new system of business start-up subsidies in Germany. This system was built in 2005 and aimed to make self-employment more attractive as an option for the unemployed. Assessment of the effects of this program showed a positive impact on reducing unemployment in the group of treated individuals. In the subsequent studies, Wolff and Nivorozhkin (2012) also evaluated the effectiveness of a self-employment program for unemployed people in Germany and Wolff et al. (2015) evaluate the long-term effectiveness of a self-employment program for welfare recipients in Germany.

Baumgartner and Caliendo (2008) evaluated the effects of two new start-up programs supporting the start of self-employment for the unemployed in Germany. The study revealed a significant positive impact of both interventions, and the authors argue that active labor market policy programs for self-employment are one of the more effective programs for the unemployed. 
In their study, Caliendo and Kunn (2015) dealt with start-up programs designed specifically for unemployed women in Germany. They found that these programs have a better success rate than traditional active labor market policy programs to start female entrepreneurship.

In the study of Caliendo et al. (2015) the authors compared companies that started their activities with the support of the start-up program with those that started without such support. The study compared not only the characteristics of individuals who started their own business, but also business results. The study indicated that start-up programs are effective, but in the business results these supported entrepreneurs (former unemployed) are lagging behind regular business founders.

Bellmann et al. (2017) in their article evaluated the programs for starting self-employment in Germany after the reform in 2011. The study found differences in the composition of participants in these programs before and after the reform and also revealed a significant positive effect of the intervention.

In Germany, several important studies have been published concerning the impact assessment of interventions. The authors focused mainly on self-employment programs such as Caliendo and Kunn (2011, 2014), Caliendo and Kritikos (2019), Caliendo et al. (2016).

Behrenz et al. (2012) evaluated the Swedish self-employment program using data from the administrative records of program participants and non-participants. The analysis found that participation in this program shortens the duration of unemployment and the risk of unemployment again. (Dvorsky et al., 2018, Olah et al., 2019a, Olah et al., 2019a, Olah et al., 2019b).

In addition to the above-mentioned studies on self-employment programs, several author studies have also been conducted in other countries, focusing on self-employment programs, but also other instruments of active labor market policy or their evaluation in general. Evaluations have been carried out, for example, in Italy: Liberto et al. (2013) as well as Sestito and Viviano (2016). In addition, studies on the evaluation of support programs have been published, for example in Belgium: Cockx and Belle (2017), in France: Duhautois (2015), in Romania: Rodríguez-Planas and Jacob (2009) and Rodriguez-Planas (2010), in Sweden: Sianesi (2002) or also in Austria: Ebbel (2014), Hungary: Oleary (1999) and Slovakia: Svabova et al. (2019b).

\section{Methodology}

In this study, we focused on analyzing the relationships between the characteristics of individuals and their success in self-employment, which they started through the start-up program for the unemployed. We consider those entrepreneurs who have maintained their activity even after the obligatory period of 3 years after the granting of subsidies to be successful. We examined whether the gender of the individual, the age group (young unemployed under 25 and older over 25), the level of education (primary, secondary and tertiary education) and the existence of a disadvantage of the unemployed (no disadvantage or at least one disadvantage) affects the result of the program.

For the analysis of relationships, we used chi-square independence test, which is very often used test to verify the independence of a pair of categorical variables. The null hypothesis of this test is that the variables are independent. The test is based on the contingency table of two variables. The principle of operation of the test is to compare the table of observed actual frequencies $O_{i j}$ with the table of theoretical expected frequencies $E_{i j}$, which are calculated according to the formula 


$$
E_{i j}=\frac{n_{i \cdot} \cdot n_{. j}}{n}
$$

where $n$ is the total number of observations in the data;

$$
\begin{aligned}
& n_{i .}=\sum_{j=1}^{s} n_{i j} \text { is the row sum of frequencies; } \\
& n_{. j}=\sum_{i=1}^{r} n_{i j} \text { is the column sum of frequencies; } \\
& i=1,2, \ldots, r ; j=1,2, \ldots, s .
\end{aligned}
$$

The test is based on the calculation of differences in observed frequencies and expected frequencies. Large differences between them indicate the dependency of the variables in the contingency table. If the differences are small, it is indicative of variables independence. The test criterion is calculated

$$
\chi^{2}=\sum_{j=1}^{s} \sum_{i=1}^{r} \frac{\left(o_{i j}-E_{i j}\right)^{2}}{E_{i j}}
$$

and the null hypothesis is rejected in case that the inequality holds

$$
\chi^{2}>\chi_{\alpha}^{2}((r-1) \cdot(s-1))
$$

for the significance level $\alpha$ (Angrist and Pischke, 2009).

In order to carry out this test, all the theoretical frequencies in the $2 \times 2$ contingency table have to be higher than 5 and none of them could be zero. In a table of dimension $r \times s$, at least $80 \%$ of the theoretical frequencies must be greater than 5 and, again, none should be zero. If this condition is not met, we will merge some categories of some variable for the $r \times s$ contingency table to ensure that the condition is met.

\section{Results}

Furthermore, we will focus on the analysis of micro-data on persons who participated in the intervention Assistance for unemployed persons to become entrepreneurs in 2015. This was the year when the program was re-started, after the previous period of its functioning from 2003 until 2007. A total of 1795 individuals participated in the program this year, of which 238 participants (i.e. $13.26 \%$ ) were young unemployed under 25 years of age. Regarding gender, 922 men and 873 women were among the participants, which is approximately $51,4 \%$ of men and $48,6 \%$ of women. Of the treated, 281 (i.e. $15.7 \%$ ) had at least one disadvantage (most often a graduate, high age, low education). The other individuals had no disadvantage.

We examined how the success of the intervention depends on the sex of the individual who started self-employment. The following association table shows the numbers of individuals by sex and program success.

Table 1: Association table of gender and success of the program

\begin{tabular}{llll}
\hline Gender*intervention success crosstabulation & yes & no & Total \\
\hline men & & & 922 \\
women & 429 & 493 & 873 \\
Total & 552 & 321 & 1795 \\
\hline
\end{tabular}

Source: Own calculation

Using the Chi-square test of independence for two categorical variables, we verified the null hypothesis of the independence of these two variables. The condition of the use of the test was 
fulfilled (all theoretical frequencies are higher than 5, the lowest frequency is 395.9). Given the p-value of the test, which is very low $(1,21 \mathrm{E}-12)$, we reject the null hypothesis of independence. Thus, in this case, it was confirmed that the success of the intervention is influenced by the sex of the individual. In terms of shares, $46.5 \%$ of treated men and $63.2 \%$ of women retained selfemployment after the mandatory period. Among those individuals, where the intervention can be considered as successful, $43.7 \%$ were men and $56.3 \%$ were women.

In an analogous way, we analyze the dependence of the success of the intervention on the individual's age, taking into account whether it was a young unemployed person under 25 or not. The following table shows the numbers of individuals treated in these age groups, divided by the success of the intervention.

Table 2: Association table of age and success of the program

\begin{tabular}{llll}
\hline Age*success crosstabulation & yes & no & Total \\
\hline under 25 & 97 & 141 & 238 \\
over 25 & 884 & 673 & 1,557 \\
Total & 981 & 814 & 1,795 \\
\hline
\end{tabular}

Source: Own calculation

This time, using the Chi-square test for these two variables, we verify the validity of the hypothesis that the success of the intervention is independent of the individual's age category. The condition of the test is fulfilled, the lowest theoretical frequency is 130,1. Again, the pvalue of the test is very low (3.77E-06), implying that the null hypothesis about the independence should be rejected. These two characteristics are significantly dependent, i.e. the success of the intervention, which we consider maintaining business for more than 3 years, depends on whether the individual is a young person under 25 or not. In percentage terms, among the young unemployed, $40.8 \%$ of the treated individuals were successful and among older individuals $56.8 \%$ were. Among those who maintained self-employment for longer than the compulsory period of 3 years, only $9.9 \%$ were younger than 25 years, the rest $(90.1 \%)$ were older than 25 years. These numbers also indicate that individuals over 25 years of age tend to remain in self-employment rather than the younger ones.

The third feature of which we examined the impact on the success of the intervention and maintaining the business for more than 3 years was disadvantages (for example, a graduate under 24, high age, low education, etc.). We have divided the beneficiaries into those who have at least one disadvantage and those who have no disadvantage. We examined whether the incidence of disadvantage has a significant effect on the success of the program. The following table shows the numbers of individuals with and without disadvantages and the numbers of successful participants in the start-up program.

Table 3: Association table of disadvantages and success of the program

\begin{tabular}{lccc}
\hline Disadvantages*success crosstabulation & yes & no & Total \\
\hline no disadvantage & 868 & 646 & 1,514 \\
at least one disadvantage & 113 & 168 & 281 \\
Total & 981 & 814 & 1,795 \\
\hline
\end{tabular}

Source: Own calculation 
By applying the Chi-square independence test, we investigated the relationship between the two variables. The condition of the test is fulfilled, the lowest theoretical frequency is 127,4 . The p-value of this test is low (1.19E-07), i.e. we reject the null hypothesis of independence, and therefore the occurrence of an individual's disadvantage is considered to have a significant effect on maintaining the length of business beyond the mandatory sustainability period. Of the individuals we consider successful, $11.5 \%$ had at least one disadvantage, the other $88.5 \%$ were without disadvantages. Among those who had at least one disadvantage, $40.2 \%$ were successful.

The last feature, on that we examined the dependence of the success of a business start-up program, was the degree of education. The levels of education were categorized as primary, secondary and tertiary education. The numbers of program participants with each level of education, divided by the program success rate, are shown in the following table.

Table 4: Association table of education and success of the program

\begin{tabular}{llll}
\hline Education*success crosstabulation & yes & no & Total \\
\hline primary education & 2 & 6 & 8 \\
secondary education & 487 & 368 & 855 \\
tertiary education & 492 & 440 & 932 \\
Total & 981 & 814 & 1,795 \\
\hline
\end{tabular}

Source: Own processing

In this case, since there were only 8 of the participants with primary education, the conditions of the chi-square test of independence were not met. The theoretical frequencies in this category of education were less than 5 (namely 4.4 and 3.6). We have therefore merged this category of education with the category of secondary education to ensure that the condition of the chisquare test of independence is met. Following this merger of categories, the p-value of the test was 0.0996 , i.e. the null hypothesis about the independence of variables, in this case, is not rejected. The level of education achieved (after the merging, primary / secondary education and tertiary education) has no significant impact on whether individuals have maintained selfemployment for longer than the prescribed mandatory period of 3 years.

\section{Discussion}

Evaluation of the success of interventions in EU countries is currently recommended by European Commission regulations but is still not common practice. These evaluations should be carried out ex-post after the end of the programs, where we can follow the evolution of the individual's career path after the mandatory program period. This can be used to assess whether the grants spent have produced the desired effect of maintaining the employment of program participants. In the case of start-up incentives to start a self-employed activity, the mandatory period of the retirement of this type of business after the grant is in Hungary for 3 years. We watched participants in these programs in Hungary one year after this compulsory business period. In this follow-up, we focused on whether the individual's characteristics (specifically gender, age category, disadvantages, and level of education) have a significant impact on the individual's treatment program being successful. By analyzing relationships in a pair of categorical variables, using the Chi-square independence tests we identified, that the gender of the program participant has a significant impact on success. In this case, women can be considered a more successful group: more women were among those individuals who were 
successful in business after the compulsory period of 5 years. At the same time, among the women, the ones for which the program was successful are prevailing.

Similar results were obtained for the age group of participants. We divided them into a group of young individuals up to 25 years of age and older applicants over 25 years of age. By applying the chi-square test, we also found in this case that the age group of individuals influences their success in maintaining self-employment. In this case, we consider those who were over 25 years of age to be more successful. Among young individuals under 25 years of age, the group of people, who no longer continue in self-employment after the mandatory sustainability of the program prevails.

Disadvantages also found a significant dependence on the success of the program to start self-employment. Among those whose intervention was successful even after the mandatory sustainability period, non-disadvantaged individuals prevail $(88.5 \%)$. Among those who had at least one disadvantage, $40.2 \%$ of individuals maintained their business for more than 3 years.

Finally, we have found that the level of education achieved does not have a significant effect on whether individuals have been able to sustain their business for more than three years. There was no significant dependence between education and this success criterion. In percentage terms, there are no large differences between successful and unsuccessful recipients of interventions at different levels of education: $56.7 \%$ are successful in primary and secondary education, $52.8 \%$ in higher education. Among those who have been successful, $49.8 \%$ have primary or secondary education and $50.2 \%$ have a university education.

Examining the results of interventions provided to the unemployed should be part of evidence-based policy-making for subsequent periods. This could help to ensure that the funds spent on these programs are used efficiently and effectively.

\section{References}

Angrist, J.D. \& Pischke, J.-S. (2009). Mostly Harmless Econometrics: An Empiricist's Companion. Princeton University Press, New York.

Baumgartner, H.J. \& Caliendo, M. (2008). Turning unemployment into self-employment: Effectiveness of two start-up programmes. Oxford Bulletin of Economics and Statistics, 70(3), 347-373.

Behrens, L., Delander, L. \& Mansson, J. (2012). Start-up Subsidies in Sweden: Treatment, Deadweight and Direct Displacement Effects. Working paper series: Linnaeus University Centre for Labour Market and Discrimination Studies; Linnéuniversitetet, 27.

Bellmann, L. et al. (2018). The post-reform effectiveness of the new german start-up subsidy for the unemployed. Labour, 32(3), 293-319.

Bergemann, A. \& Berg, V.D. (2008). Active labor market policy effects for women in europe - A survey. Annales DÉconomie Et De Statistique, 91/92, 385.

Blanchflower, D. \& Oswald, A. (1990). What Makes an Entrepreneur? Evidence on inheritance and capital Constraints. Journal of Labor Economics, 16(1), 26-60.

Caliendo, M. (2016). Start-Up Subsidies for the Unemployed: Opportunities and Limitations. IZA World of Labor.

Caliendo, M. \& Künn, S. (2011). Start-up subsidies for the unemployed: Long-term evidence and effect heterogeneity. Journal of Public Economics, 95(3-4), 311-331.

Caliendo, M. \& Künn, S. (2015). Getting back into the labor market: The effects of start-up subsidies for unemployed females. Journal of Population Econmics, 28(4), 1005-1043.

Caliendo, M. \& Künn, S. (2014). Regional effect heterogeneity of start-up subsidies for the unemployed. Regional Studies, 48(6), 1108-1134.

Caliendo, M. et al. (2015). Subsidized Start-Ups out of unemployment: A comparison to regular business startups. Small Business Economics, 45(1), 165-190.

Caliendo, M., Künn, S. \& Weißenberger, M. (2016). Personality traits and the evaluation of start-up subsidies. European Economic Review, 86, 87-108.

Caliendo, M. \& Kritikos, A.S. (2019). "I want to, but i also need to": Start-Ups resulting from opportunity and necessity. From Industrial Organization to Entrepreneurship, 247-265. 
Cockx, B.L.W. \& Van Belle, E. (2019). Waiting longer before claiming, and activating youth: No point? International Journal of Manpower, 40(4,) 658-687.

Crépon, B., Duflo, E., Gurgand, M., Rathelot, R. \& Zamora, P. (2013). Do labor market policies have displacement effects? Evidence from a clustered randomized experiment*. The Quarterly Journal of Economics, 128(2), 531-580.

Duhautois, R., Redor, D. \& Desiage, L. (2015). Long term effect of public subsidies on start-up survival and economic performance: an empirical study with french data. Revue Déconomie Industrielle, 149, 11-41.

Dvorsky, J., Popp, J., Virglerova, Z., Kovacs, S. \& Olah, J. (2018). Assessing the importance of market risk and its sources in the SME of the Visegrad Group and Serbia. Advances in Decision Sciences, 22(A) 22nd Anniversary Special Issue, 1-25.

Eppel, R. (2016). The effects of a job-creation scheme: Evidence from regional variation in program capacities. Industrial Relations: A Journal of Economy and Society, 56(1), 161-190.

Fertig, M. \& Csillag, M. (2015). Cost-benefit Analysis of Remedial Interventions for the Long-Term Unemployed. European Comission, European Union.

Hottenrott, H. \& Richstein, R. (2020). Start-up subsidies: Does the policy instrument matter? Research Policy, 49(1), 103888.

Hungary Country Note. (2018). Inclusive Entrepreneurship Policies: Country Policy Assessment. European Comission. OECD/European Union.

Liberto, A.Di et al. (2013). Employment subsidies, informal economy and womens transition into work in a depressed area: Evidence from a matching approach. SSRN Electronic Journal.

Olah, J., Virglerova, Z., Kliestikova, J., Popp, J. and Kovacs, S. (2019a). The assessment of non-financial risk sources of SMEs in the V4 countries and Serbia. Sustainability, 11(17), 4806, 1-19.

Olah, J., Kovacs, S., Virglerova, Z., Lakner, Z. and Popp, J. (2019B). Analysis and comparison of economic and financial risk sources in SMEs of the Visegrad group and Serbia, Sustainability, 11(7), 1853, 1-19.

Oleary, C.J. (1999). Promoting self employment among the unemployed in hungary and poland. Upjohn Institute Working Paper, 99-55. Kalamazoo, MI: W.E. Upjohn Institute for Employment Research.

Rodríguez-Planas, N. \& Jacob, B. (2009). Evaluating active labor market programs in Romania. Empirical Economics, 38(1), 65-84.

Rodriguez-Planas, N. (2010). Channels through which public employment services and small-business assistance programs work. Oxford Bulletin of Economics and Statistics, 72(4), 458-485.

Sestito, P. \& Viviano, E. (2016). Hiring incentives and/or firing cost reduction? evaluating the impact of the 2015 policies on the italian labour market. SSRN Electronic Journal.

Sianesi, B. (2002). An evaluation of the Swedish system of active labour market programmes in the 1990s. Working Paper Series.

Svabova, L., Durica, M. \& Kliestik, T. (2019a). Modelling the costs of unemployment for young graduates in Slovakia: A counterfactual approach. Politická Ekonomie, 67(5), 552-566.

Svabova, L., Durica, M., Kramarova, K., Valaskova, K., Janoskova, K. (2019b). Employability and sustainability of young graduates in the Slovak labour market: Counterfactual Approach. Sustainability, 11(16), 4462.

Tokila, A. (2009). Start-up grants and self-employment duration. Working paper, School of Business and Economics, University of Jyv“askyl“a.

Verheul, I., Thurik, R., Grilo, I. \& Zwan, P.V.D. (2012). Explaining preferences and actual involvement in selfemployment: Gender and the entrepreneurial personality. Journal of Economic Psychology, 33(2), 325-341.

Wolff, J. \& Nivorozhkin, A. (2012). Start me up: The effectiveness of a self-employment programme for needy unemployed people in Germany. Journal of Small Business \& Entrepreneurship, 25(4), 499-518.

Wolff, J., Nivorozhkin, A. \& Bernhard, S. (2015). You can go your own way! The long-term effectiveness of a self-employment programme for welfare recipients in Germany. International Journal of Social Welfare, 25(2), 136-148. 